\title{
Nutrient management through organic and inorganic manures in coconut (Cocos nucifera L.) Garden
}

\section{H.J. SENJALIYA, G.S. VALAAND G.S. MANGROLIYA}

Received : 14.11.2014; Revised : 17.04.2015; Accepted : 25.04 .2015

MEMBERS OF RESEARCH FORUM:

Corresponding author: H.J. SENJALIYA, Agricultural Research Station (fruit crop), Junagadh Agricultural University, MAHUVA (GUJARAT) INDIA

\section{Co-authors :}

G.S. VALA AND G.S. MANGROLIYA, Agricultural Research Station (fruit crop), Junagadh Agricultural University, MAHUVA (GUJARAT) INDIA

\begin{abstract}
Summary
A field experiment was conducted at the Agricultural Research Station (fruit crops), Junagadh Agricultural University, Mahuva during the year 2004-2009 to study the nutrient management in coconut garden through organic and inorganic manuers. The experiment was laid out in Randomized Block Design with three replications. There were 10 treatments. The analysis of five year pooled data revealed that the treatment $\mathrm{T}_{7}(50 \% \mathrm{RDF}+50 \% \mathrm{~N}$ from castor cake) recorded significantly higher nut yield (78.33 nut/palm/year). Nut quality and soil properties were also improved by $\mathrm{T}_{7}$.
\end{abstract}

Key words : Coconut, Organic, inorganic, Castor cake, Fertilizer

How to cite this article : Senjaliya, H.J., Vala, G.S. and Mangroliya, G.S. (2015). Nutrient management through organic and inorganic manures in coconut (Cocos nucifera L.) Garden. Asian J. Soil Sci., 10(1) : 59-62. 